\title{
Theoretical models for the control of bacterial growth rate, abundance, diversity and carbon demand
}

\author{
T. Frede Thingstad ${ }^{1, *}$, Risto Lignell ${ }^{2}$ \\ ${ }^{1}$ Dept of Microbiology, University of Bergen, Jahnebk. 5, N-5020 Bergen, Norway \\ ${ }^{2}$ Dept of Limnology, PO Box 27, University of Helsinki, FIN-00014 Helsinki, Finland
}

\begin{abstract}
Our conceptual understanding of the role of heterotrophic bacteria in pelagic ecosystems and in ocean biogeochemical cycles is closely linked to our understanding of how their growth rate, abundance, and diversity is controlled. Here we discuss consequences of the simplifying assumption that there are only 5 potentially important interactions between heterotrophic bacteria and their biological and chemical environment. We consider 3 possible types of growth rate limitation: (1) organic carbon, (2) inorganic phosphate, and (3) organic and inorganic nitrogen; and 2 types of cell losses: (1) predation by heterotrophic flagellates, or (2) lysis by infectious viruses. Incorporating this into simple food web structures, we discuss 4 classes of models, 2 based on carbon limitation and 2 based on mineral nutrient limitation of bacterial growth rate. Bacterial abundance is assumed to be controlled by protozoan predation in all cases. For each class, we derive expressions describing bacterial carbon demand, and discuss the control of bacterial carbon demand, growth rate and diversity. It is shown how models predicting an ecosystem production of dissolved organic carbon (DOC) exceeding bacterial carbon demand may be constructed assuming either a low degradability of the DOC, or mineral nutrient limitation of bacterial growth rate. For 2 classes of models, infectious viruses are shown to affect neither growth rate nor abundance of the steady state bacterial community. For all 4 classes of models, viruses are suggested to control diversity of the steady state bacterial community
\end{abstract}

KEY WORDS: Bacteria - Models · Degradation - Growth rate - Limitation · Predation · Viral lysis

\section{INTRODUCTION}

Microbial ecology has been a field severely restricted by the shortage of adequate methods for observation and description of natural mixed communities of bacteria, viruses, and auto- and heterotrophic protists. As a natural consequence, there has been a large emphasis on the development of methods. This approach has proven successful through the many major shifts in conceptual understanding which have been closely linked to improvements in methodology. Central examples would be the introduction of fluorescence microscopy for enumeration of bacterial abundance (Zimmermann \& Meyer-Reil 1975), the use of

\footnotetext{
•E-mail: frede.thingstad@im.uib.no
}

thymidine incorporation to measure bacterial production (Fuhrman \& Azam 1982), flow cytometry to enumerate prochlorophytes (Olsen et al. 1991), ultracentrifugation to enumerate viruses (Bergh et al. 1989), and recently also molecular techniques to estimate diversity of the bacterial community (e.g. Rehnstam et al. 1993, Fuhrman et al. 1994, Höfle \& Brettar 1995). In this situation, it is a natural consequence that much effort has been focused on measurement and description, perhaps with fewer endeavours focused on the understanding of underlying ecological mechanisms regulating measured values like production, abundance, growth rate or diversity. As a result, the present situation contains an element of discomfort with, on one side, pieces of information of obviously great importance to our understanding of the role of heterotrophic bacteria in the ocean, and, on the other side, the 
lack of a unifying conceptual framework within which these pieces of observation can be related and discussed. Such pieces of information include the observations of accumulation (Williams 1995), yet degradability (Kirchman et al. 1991), of dissolved organic carbon (DOC) in surface waters; mineral nutrient, rather than organic carbon limitation of bacteria (Pomeroy et al. 1995); unexpectedly low bacterial diversity in pelagic systems (Rehnstam et al. 1993, Höfle \& Brettar 1995); and the dominance of lytic, rather than lysogenic, cycles in bacteria-virus interactions (Wilcox \& Fuhrman 1994).

We acknowledge that the question of bacterial physiology during growth under sub-optimal conditions is a complex issue. Perhaps even more complex is the issue of interactions between bacteria and their trophic neighbours in the food web. One could, with some justification, argue that a major feature of such ecological systems perhaps is complexity itself, and that trying to understand them from drastically simplified models automatically means disregarding some of their essential features. We feel, however, that the opposite argument is potentially a more fruitful one: with a poor ability to intuitively grasp the behaviour of complex dynamic systems, the human mind may need the aid of simplified models to try to extract essential features from a complex and sometimes bewildering reality. The objective of the present study is thus to try to understand the consequences of making simplified assumptions concerning the control of bacterial activity, abundance and diversity. Here we explore theoretical consequences of the assumption that there are only 5 potential factors in the biological/chemical environment which influence the heterotrophic bacteria: substrates in the form of (1) DOC, (2) inorganic phosphate, or (3) organic/inorganic nitrogen, (4) protozoan predation, and (5) lysis by infectious viruses. Thingstad et al. (1997) have previously shown how mineral nutrient limited bacteria, being 'sandwiched' between competition for mineral nutrients and predation by protozoa, may be unable to consume the degradable DOC produced in the food web. Also, Thingstad et al. (in press) have discussed how lytic viruses, predation, and system nutrient content link together into a hierarchical system controlling bacterial diversity.

Here we combine elements from these previous analyses with discussions of

- the effect of low degradability of DOC.

- the effect of viruses on element flows, and

- the potential effect of organic forms of nutrients

like nitrogen and phosphorus,

and suggest that one can separate plausible models for the control of bacteria into (at least) 4 different classes.

If, as a starting point, we regard only the factors directly influencing the heterotrophic bacteria, without

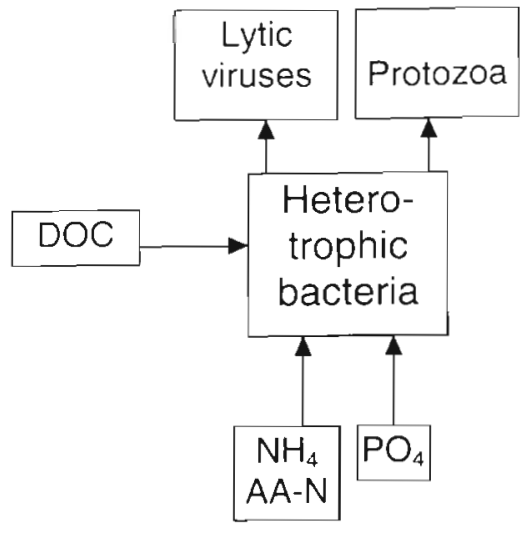

Fig. 1. The 5 possible interactions considered between heterotrophic bacteria and their chemical/biological environment

putting them into any food web context, the simplifying idea of 5 potentially controlling factors are as illustrated in Fig. 1.

Independent of any further considerations, the bacterial carbon demand $(R)$ is by definition given as:

$$
R=Y_{\mathrm{BC}}^{-1} \mu_{\mathrm{B}} B
$$

where $Y_{\mathrm{BC}}, \mu_{\mathrm{B}}$, and $B$ are bacterial yield on the carbon source, bacterial growth rate, and bacterial abundance, respectively. (Symbols summarized in Table 1.) Understanding how bacterial carbon demand is regulated is thus equivalent to understanding how physical, chemical, and biological factors influence $Y_{\mathrm{BC}}, \mu_{\mathrm{B}}$ and $B$. For the rest of our discussion, we will make the simplifying assumption that $Y_{\mathrm{BC}}$ is a constant.

Within this framework, one may imagine at least 4 different possible classes of mechanisms based on differences in the limitation of specific bacterial growth rate $\mu_{\mathrm{B}}$ : (1) growth rate limitation due to lack of organic carbon, (2) low maximum growth rate caused by the chemical nature of the organic material available, (3) growth rate limitation due to lack of elements like $N$ or $\mathrm{P}$ available in inorganic forms, and (4) growth rate limitation due to a lack of elements like $\mathrm{N}$ or $\mathrm{P}$, available as inorganic and organic compounds.

For all of these growth rate limitations, we assume bacterial abundance $B$ to be controlled by predation from heterotrophic flagellates.

According to ilte numibering above, we will refer to models building on the 4 types of limitation as Class 1 to Class 4 models, respectively.

For simplicity, we will discuss Class 3 as limitation by orthophosphate, with no reference to any possible role of organic P-compounds. Class 4 we will discuss as limitation by a combination of inorganic forms of $\mathrm{N}$ and amino acids, and with bacteria being the only utilisers of amino acid- $N$. The principles in both classes may however refer to both $\mathrm{N}$ and $\mathrm{P}$ limitation. 
Table 1. Symbols used

\begin{tabular}{|c|c|c|}
\hline & & Typical unit \\
\hline \multicolumn{3}{|c|}{ Abundances } \\
\hline$B$ & Abundance of heterotrophic bacteria & cells $1^{-1}$ \\
\hline$P$ & Abundance of heterotrophic flagellates & cells $]^{-1}$ \\
\hline$A$ & Abundance of phytoplankton & cells $]^{-1}$ \\
\hline$N$ & Concentration of limiting mineral nutrient & mol $1^{-1}$ \\
\hline$V_{1}$ & Abundance of viruses in the $i$ th virus-host system & virus $l^{-1}$ \\
\hline$H$ & Abundance of bacterial hosts in the $i$ th virus-host system & cells $1^{-1}$ \\
\hline \multicolumn{3}{|c|}{ Affinity (and equivalent) constants } \\
\hline$\alpha_{\mathrm{B}}$ & Bacterial affinity for limiting mineral nutrient & $1 \operatorname{cell}^{-1} h^{-1}$ \\
\hline$\alpha_{\mathrm{A}}$ & Phytoplankton affinity for limiting mineral nutrient & $1 \mathrm{coll}^{-1} \mathrm{~h}^{-1}$ \\
\hline$\alpha_{\mathrm{p}}$ & Heterotrophic flagellate clearance rate for bacterial prey & l cell $1^{-1} \mathrm{~h}^{-1}$ \\
\hline$\alpha_{C}$ & Ciliate clearance rate for phytoplankton and bacterivorous flagellates & l cell ${ }^{-1} \mathrm{~h}^{-1}$ \\
\hline$\alpha_{V}$ & Adsorption coefficient of the $i$ th virus-host system & l virus ${ }^{-1} h^{-1}$ \\
\hline \multicolumn{3}{|c|}{ Specific loss rates } \\
\hline$\delta_{\mathrm{A}}$ & Specific loss rate of phytoplankton & $h^{-1}$ \\
\hline$\delta_{\mathrm{p}}$ & Specific loss rate of bacterivorous heterotrophic flagellates & $h^{i}$ \\
\hline$\lambda_{1}$ & Decay rate of the $i$ th virus population & $h^{-1}$ \\
\hline \multicolumn{3}{|c|}{ Specific growth rates } \\
\hline$\mu_{\mathrm{B}}$ & Bacterial specific growth rate & $\mathrm{h}^{-1}$ \\
\hline$\mu_{\mathrm{B}}^{\mathrm{mdx}}$ & Maximum bacterial specific growth rate on the available carbon source & $h^{-1}$ \\
\hline \multicolumn{3}{|c|}{ Yield (and equivalent) coefficients } \\
\hline$Y_{\mathrm{BC}}$ & Bacterial yield on organic carbon & cells $\mathrm{mol}^{-1}$ \\
\hline$Y_{\mathrm{BN}}$ & Bacterial yield on nitrogen & cells $\mathrm{mol}^{-1}$ \\
\hline$Y_{\mathrm{A}}$ & Phytoplankton yield on limiting mineral nutrient & cells $\mathrm{mol}^{-1}$ \\
\hline$Y_{p}$ & Heterotrophic flagellate yield on bacteria & cells cell ${ }^{-1}$ \\
\hline$m_{1}$ & Multiplicity; number of viruses released per lysed bacterial host in the $i$ th virus-host system & virus cell ${ }^{-1}$ \\
\hline \multicolumn{3}{|c|}{ Production and consumption rates for dissolved compounds } \\
\hline$\psi_{\mathrm{C}}$ & System production rate for DOC & $\mathrm{mol} \mathrm{\textrm {l } ^ { - 1 }} \mathrm{h}^{-1}$ \\
\hline$\psi_{N}$ & System production rate of DON & $\mathrm{mol} \mathrm{l} \mathrm{l}^{-1} \mathrm{~h}^{-1}$ \\
\hline$R$ & Bacterial carbon demand & $\operatorname{mol~l} l^{-1} h^{-1}$ \\
\hline \multicolumn{3}{|l|}{ Other } \\
\hline $\mathrm{n}$ & Number of dominant bacterial species (host-types) & Dimensionless \\
\hline
\end{tabular}

Here we explore some of the steady state aspects of these 4 different classes of models when they are integrated into the framework of simple food webs linking bacteria to their trophic neighbours, protists and viruses.

\section{CLASS 1 MODELS: BACTERIAL GROWTH RATE LIMITATION CAUSED BY LACK OF AVAILABLE CARBON}

The steady state is in this case characterized by a bacterial carbon demand $\left(R_{1}\right.$, numeral subscript used to signify the class of model in question) which equals the rate $\psi_{C}$ at which degradable organic carbon is produced in the ecosystem:

$$
R_{1}=\psi_{C}
$$

If not, degradable organic carbon would accumulate, and organic carbon would no longer be a limiting factor.

This type of models seems often, explicitly or implicitly, to be assumed. The suggested paradox of nutrient limited phytoplankton stimulating their bacterial competitors for mineral nutrients (Bratbak \& Thingstad $1985)$ is one example. In a review article on bacterial consumption of inorganic nutrients, Kirchman (1994) explicitly stated the consequences of the idea of carbon limited bacteria in the pelagic photic zone: '. .. bacteria are getting all the $\mathrm{Pi}$ and $\mathrm{NH}_{4}{ }^{+}$they need at low in situ concentrations; it's the phytoplankton that need more. Bacteria cannot use more inorganic $N$ and $P$ because they are limited by organic $\mathrm{C}$, which is provided ultimately by phytoplankton'. Stable coexistence of heterotrophic bacteria and mineral nutrient limited phytoplankton in this case poses no theoretical problem since there are 2 different resources. Unfortunately, the construction of food web models in this case becomes difficult (Thingstad 1992) because bacterial production will be proportional to the rate $\psi_{C}$ at which DOC is produced. This production is the sum of release and excretion processes, probably occurring at a multitude of different locations in the food web; these processes are still poorly understood or at least poorly quantified. 
As a first approximation to the process of bacterivory, let us assume predation to be by a non-selective population of heterotrophic flagellates, i.e. by one which will eat all bacteria with the same clearance rate $\alpha_{p}$.

The equilibrium condition for heterotrophic flagellates $(P)$ in the simple predator-prey food chain of Fig. 2 requires heterotrophic flagellate production to equal loss, i.e.:

$$
Y_{\mathrm{p}} \alpha_{\mathrm{P}} B P=\delta_{\mathrm{P}} P
$$

or, by rearrangement:

$$
B^{*}=\frac{\delta_{\mathrm{p}}}{Y_{\mathrm{p}} \alpha_{\mathrm{p}}}
$$

where $Y_{\mathrm{p}}$ and $\mu_{\mathrm{p}}$ are the yield of heterotrophic flagellates on bacteria and the specific loss rate of the heterotrophic flagellates, respectively. ' is used throughout to denote equilibrium solutions. Since bacterial production in this case is controlled by the rate $\left(\psi_{C}\right)$ at which the system produces degradable DOC, bacterial growth rate is given from the equation:

$$
\psi_{\mathrm{C}}=Y_{\mathrm{BC}}^{-1} \mu_{\mathrm{B}} B
$$

which, by insertion of Eq. (4), can be solved for bacterial growth rate $\mu_{\mathrm{B}}$ :

$$
\mu_{\mathrm{B}}^{*}=Y_{\mathrm{BC}} Y_{\mathrm{P}} \frac{\alpha_{\mathrm{P}}}{\delta_{\mathrm{P}}} \psi_{\mathrm{C}}
$$

Bacterial growth rate thus becomes a function not only of the production rate of $\operatorname{DOC}\left(\psi_{C}\right)$ and the physiological properties of bacteria $\left(Y_{\mathrm{BC}}\right)$, but also of the physiological properties of their predators $\left(Y_{p}, \alpha_{p}\right)$ and the process regulating the loss of their predators $\left(\delta_{p}\right)$.

\section{CLASS 2 MODELS: DOC ACCUMULATION DUE TO LOW DEGRADABILITY}

As a variation on the theme of C-limited bacteria, one may assume that the organic molecules are of a nature allowing only a low maximum bacterial growth rate $\mu_{B}^{\max }$.

Using the same non-specific model for predation on bacteria as above, insertion of Eq. (4) into Eq. (1) gives the bactenal carbon demand as:

$$
R_{2}^{*}=\left(Y_{\mathrm{BC}} Y_{\mathrm{P}}\right)^{-1} \frac{\mu_{\mathrm{B}}^{\max } \delta_{\mathrm{P}}}{\alpha_{\mathrm{P}}}
$$

Although there may be high concentrations of the organic C-source, one would probably still tend to use the term carbon limitation in this case since addition of a more easily degradable organic $C$-source would increase growth rate. Despite the carbon limitation, $R_{2}$ is now independent of DOC production rate $\psi_{C}$ (pro-

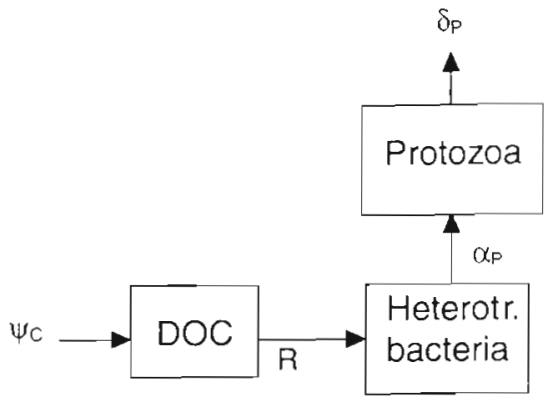

Fig. 2. Model with bacterial growth rate controlled by production rate (Class 1) or degradability (Class 2) of dissolved organic carbon

vided $\psi_{\mathrm{C}}>R_{2}$ ). With this type of model, one may therefore have stable situations with DOC accumulating because of the combination of low degradability of the material and the control of bacterial abundance exerted by the heterotrophic flagellates.

\section{CLASS 3 MODELS: MINERAL NUTRIENT LIMITED BACTERIA}

To assume an equilibrium with simultaneous limitation of phytoplankton and heterotrophic bacteria by the same mineral nutrient implies the assumption of a stable coexistence of 2 populations competing for 1 resource. Within the framework of simple models considering competition as the only trophic interaction in an environment homogeneous in time and space, such stable coexistence is not possible (Maynard Smith 1974). The situation thus (artificially) appears to pose a theoretical problem. Making the usual assumption that bacteria have a higher affinity $\left(\alpha_{B}\right)$ for mineral nutrients (here phosphate) than that of phytoplankton $\left(\alpha_{A}\right)$, one could argue that bacteria should outcompete the phytoplankton, i.e. that they would reduce the phytoplankton stock until carbon production in the system reached a sufficiently low level for the bacteria to become C-limited, in which case the system would switch to what we here have called Class 1 models. As shown by Thingstad et al. (1997), however, this is prevented by the assumed protozoan control of bacterial abundance. In the simple food web of Fig. 3, ine equiliuriun cunuition that phitytoplankton growth must equal loss gives:

or:

$$
Y_{\mathrm{A}} \alpha_{\mathrm{A}} \mathrm{NA}=\delta_{\mathrm{A}} A
$$

$$
N^{*}=Y_{\mathrm{A}}^{-1} \frac{\delta_{\mathrm{A}}}{\alpha_{\mathrm{A}}}
$$

where $N$ is the concentration of the limiting mineral nutrient, $A$ is phytoplankton abundance, and $Y_{A_{1}} \alpha_{A_{1}}$ and $\delta_{\mathrm{A}}$ are the phytoplankton yield on limiting mineral 
nutrient, their affinity for the nutrient, and their specific loss rate, respectively.

Assuming growth rate of mineral nutrient limited bacteria to increase linearly with nutrient concentration (probably a reasonable assumption for low nutrient concentrations):

$$
\mu_{\mathrm{B}}=Y_{\mathrm{BN}} \alpha_{\mathrm{B}} N
$$

where $\alpha_{\mathrm{B}}$ and $Y_{\mathrm{BN}}$ are the bacterial affinity for the mineral nutrient, and the bacterial yield on the mineral nutrient, respectively. Insertion of Eq. (9) into Eq. (10) gives an estimate of bacterial growth rate at steady state:

$$
\mu_{\mathrm{B}}^{*}=\frac{Y_{B N} \alpha_{B}}{Y_{A} \alpha_{A}} \delta_{A}
$$

and thereby, from insertion of Eqs. (11) \& (4) into Eq. (1), the following expression for $R_{3}^{*}$ :

$$
R_{3}^{*}=\frac{Y_{\mathrm{BN}}}{Y_{\mathrm{BC}} Y_{\mathrm{A}} Y_{\mathrm{P}}}-\frac{\alpha_{\mathrm{B}}}{\alpha_{\mathrm{A}} \alpha_{\mathrm{P}}} \delta_{\mathrm{A}} \delta_{\mathrm{P}}
$$

As in Class 2, we again have a situation where DOC may be produced faster than it is degraded. This occurs when $\psi_{C}>R_{3}^{*}$. This time, however, the accumulating DOC may in principle be easily degradable. Addition of an organic C-source like e.g. glucose to such a system should have no effect on the bacteria. If this class of models reflects the status in natural waters, the mechanisms of DOC production incorporated into models will be reflected in the rate at which DOC accumulates, but have no consequences for bacterial activity and abundance (as long as $\psi_{C}>R_{3}{ }^{\circ}$ ).

An interesting aspect of this type of model is the role of the loss rate of bacterial competitors $\left(\delta_{A}\right)$ and predators $\left(\delta_{\mathrm{p}}\right)$. This is illustrated if we assume that there is a common and non-selective 'ciliate' type predator (abundance $C$ ) which preys on both the phytoplankton

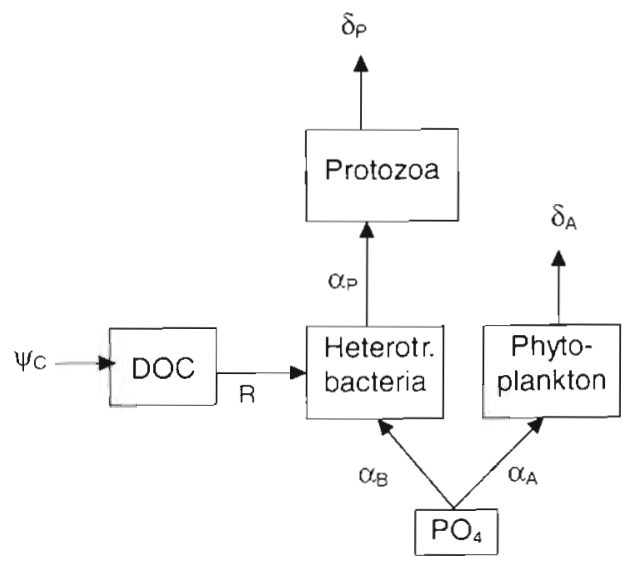

Fig. 3. Class 3 model with bacteria 'sandwiched' between algal-bacterial competition for a limiting inorganic nutrient (phosphate) and predation from heterotrophic flagellates and the bacterial predator at a clearance rate $\alpha_{C}$ so that:

$$
\delta_{\mathrm{A}}=\delta_{\mathrm{p}}=\alpha_{\mathrm{C}} \mathrm{C}
$$

Insertion into Eq. (12) then gives a bacterial production proportional to the square of ciliate abundance:

$$
R_{3}^{\cdot}=\frac{Y_{\mathrm{BN}}}{Y_{\mathrm{BC}} Y_{\mathrm{A}} Y_{\mathrm{P}}} \frac{\alpha_{\mathrm{B}} \alpha_{\mathrm{C}}^{2}}{\alpha_{\mathrm{A}} \alpha_{\mathrm{P}}} C^{2}
$$

Eq. (14) illustrates how the concepts of top-down and bottom-up control may become somewhat blurred once the food web is no longer linear: the quadratic relationship between ciliate abundance and bacterial production is a result of a combined top-down (ciliates removing bacterial predators) and bottom-up (removal of competitors) effect.

\section{CLASS 4 MODELS: COMBINATION OF INORGANIC AND ORGANIC FORMS OF THE NUTRIENTLIMITING BACTERIAL GROWTH RATE}

The major difference between $\mathrm{N}$ and $\mathrm{P}$ limitation within the scheme of Fig. 1 is the inclusion of a possible organic $\mathrm{N}$-source (amino acids) for $\mathrm{N}$. If, as a first approximation, we assume amino acids to be consumed only by bacteria (Fig. 4), bacterial carbon demand (Eq. 12) will increase with a term proportional to the rate $\Psi_{N}$ at which amino acid- $N$ is produced in the system:

$$
R_{4}^{*}=\frac{Y_{B N}}{Y_{B C}}\left(\frac{1}{Y_{A} Y_{P}} \frac{\alpha_{B}}{\alpha_{A} \alpha_{P}} \delta_{A} \delta_{P}+\psi_{N}\right)
$$

The increase in $R$ caused by $\psi_{N}$ could be argued to reduce the probability that bacterial carbon demand will be less than DOC production (i.e. that $R_{4}^{*}<\psi_{C}$ ).

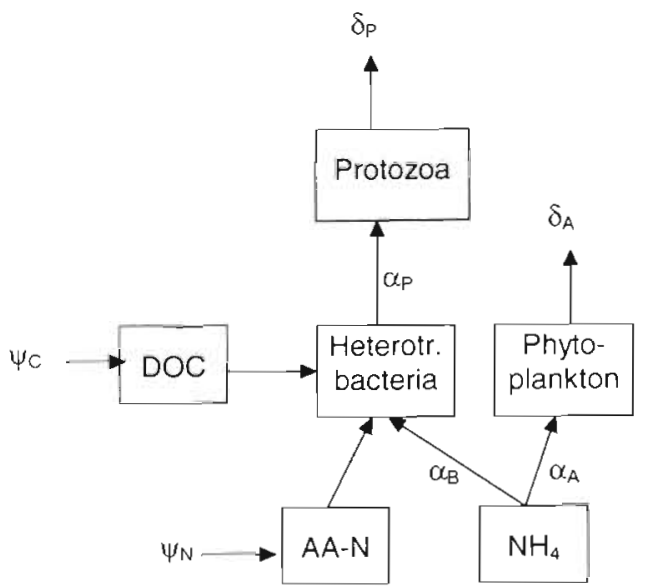

Fig. 4. Class 4 model with bacteria being the only consumer of dissolved $\mathrm{N}$ being able to utilize amino acid- $\mathrm{N}$ 
If such an argument is correct, and if our Class 4 model is valid for nitrogen, but not for phosphorus, one could argue that mineral nutrient limitation of bacteria is more probable in P-than in N-deficient systems. Such a difference between $\mathrm{P}$ and $\mathrm{N}$ limitation is, however, not necessarily the case in reality. Although the phosphate group of organic phosphate molecules is usually assumed to be split off from the organic part before uptake through the membrane, cell bound coupling of hydrolysis and uptake may occur (Ammerman \& Azam 1991). If such coupling is a feature more characteristic for bacteria than for phytoplankton, models of Class 4 could also be relevant in P-deficient systems. Our assumption of bacteria being the only group able to harvest nitrogen from the pool of amino acids may also be an oversimplification. Phytoplankton enzymes that are at least able to oxidise amino acids and produce ammonia have been demonstrated in seawater (Pantoja \& Lce 1994)

\section{ROLE OF LYTIC VIRUSES}

With our assumption of a non-selective bacterial predator preying only on live bacteria, bacterial abundance is controlled by the heterotrophic flagellates in all 4 cases above (Eq. 4). The perhaps somewhat unexpected conclusion is that viral lysis should not have any effect on the total abundance of bacteria at steady state in any of the 4 model classes. Viral lysis presumably releases a lot of the organic material from the lysed host as DOC and dissolved organic nitrogen, and should thus give increased production rates $\psi_{\mathrm{C}}$ and $\psi_{\mathrm{N}}$. From the equation derived for $R$ (Eqs. 2, 7, 12 \& 15), viral lysis would thus be expected to increase bacterial carbon demand in Class 1 and Class 4 models, but not in Classes 2 and 3 . Since abundance is controlled by predation and bacterial yield is assumed to be constant, this is equivalent to saying that bacterial growth rate at steady state is affected by lytic viruses only in Class 1 and 4 models.

Viral production may be either by lytic or by lysogenic cycles. In the lytic case an infection starts a process leading rapidly to cell lysis and release of new, infectious viruses. In the lysogenic case, the virus is incorporated into the DNA of the host and carned on to the daughter cells until some process induces the virus production and cell lysis at, potentially, a much later stage. If selectively killing 'winner' (i.e. superior competitor) populations, both mechanisms would promote diversity in the bacterial population, but the lysogenic one, with lysis potentially induced by a range of external influences, seems difficult to incorporate into simple models. Wilcox \& Fuhrman (1994) have recently suggested from experimental data that the lytic cycle is the dominant process. In our Class 3 model, we used a bacterial predator, selective for bacteria, but nonselective among bacteria, as a mechanism to 'kill the winner', i.e. to suppress the superior competitor for mineral nutrients. This allowed coexistence of phytoplankton and bacteria. An analogous argument for Iytic viruses would give an equilibrium concentration $H_{i}^{*}$ of the $i$ th type bacterial hosts at which production rate balances decay rate for the corresponding virus (Thingstad et al. in press). $H_{i}$ is given by an equation analogous to Eq. (4), but with viral decay rate $\lambda_{l}$ viral multiplicity $m_{i}$, and viral adsorption coefficient $\alpha_{V_{i}}$ replacing the protozoan loss rate, yield, and clearance rate, respectively:

$$
H_{i}^{*}=\frac{\lambda_{1}}{\left(m_{1}-1\right) \alpha_{V_{i}}}
$$

where 1 is subtracted from the multiplicity to account for viruses lost due to infection. Any bacterial winner increasing in abundance beyond this level will trigger a positive net production of its viruses and will produce a 'killing the winner' mechanism based on viral host-specificity. In such a model the viruses will prevent any single bacterial species (host) whose equilibrium size was determined by protozoan grazing from filling the whole community.

Maximum diversity of the bacterial community is obtained if all host populations are equal. The ratio between the total bacterial abundance $B$ and the abundance $H_{i}$ in each host group will then give the number of dominant bacterial species (dividing Eq. 4 by Eq. 16):

$$
n^{*}=\frac{B^{*}}{H_{i}^{*}}=\frac{\delta_{\mathrm{P}}}{\lambda_{i}} \frac{\left(m_{i}-1\right)}{Y_{\mathrm{P}}} \frac{\alpha_{\mathrm{p}}}{\alpha_{V_{i}}}
$$

This combined control of community size and diversity by protozoa and lytic viruses is illustrated in Fig. 5.

\section{DISCUSSION}

The strength of the types of models used above lies in their simplicity: it is reasonably easy to see the connection between assumptions made and conclusions drawn. More complicated models may potentially be more redilisic in the sense hinat they cân pioduce timedependent curves of variables more precisely following the variation observed in experiments or natural systems. Our ability to 'understand' the link between assumptions and model output, however, decreases rapidly with model complexity. As pointed out in the 'Introduction', complexity may in itself be felt to be an important property of food webs, and experimentalists familiar with the complexity of natural food webs are perhaps liable to argue that the models analyzed 


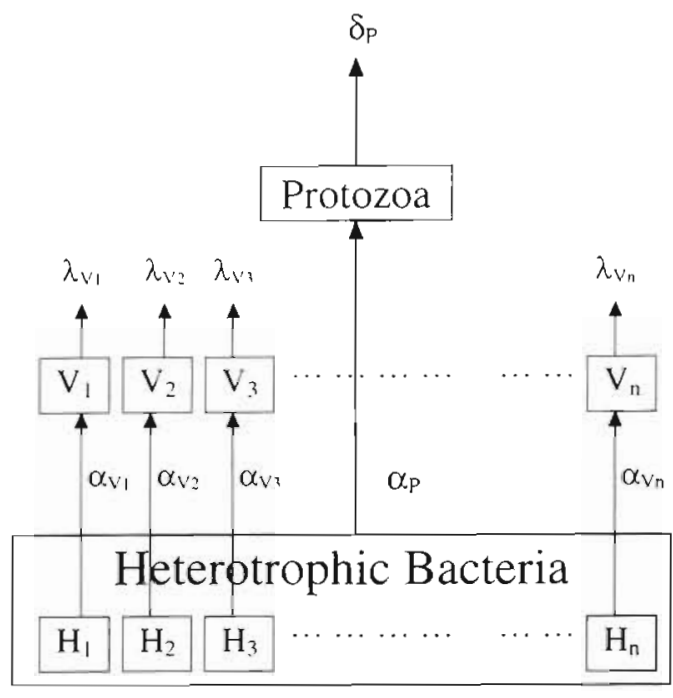

Fig. 5. Illustration of the hypothesized diversity control in the community of heterotrophic bacteria. In this idealized version, equilibrium size of the total bacterial community is determined by grazing from heterotrophic flagellates, non-selective among bacteria. Size of each bacterial host-population is regulated by host-specific infectious viruses, i.e. there is enough bacteria for protozoan loss to be balanced by grazing, and there are enough hosts for production to balance loss of each type of virus. The number of dominant bacterial species is then given as the ratio between the size of the total community and the average size of the host population. External processes influencing the specific loss/decay rates $\delta_{p}$ and $\lambda_{V}$ influence this ratio

above are not only too simple, but perhaps even simplistic. We would argue that this can only be judged from model performance which in this case is the ability to derive fundamental properties from a minimum set of assumptions. A model with only competitors would obviously be too simple for addressing the questions of diversity and bacteria-phytoplankton coexis- tence. We feel that the slightly more elaborate food webs discussed here, combining competitors with different bacterial substrates, predators, and viruses, constitute an important extension which broadly extends the range of aspects which can be analyzed. In some environments one may restrict the number of potentially interesting models to fewer than the 4 classes discussed here (summarized in Table 2). An obvious example is light-limited environments such as the deep ocean, or winter seasons at high latitudes, where mineral nutrient limitation of bacteria and algal-bacterial competition as considered in Classes 3 and 4 presumably can be ruled out. Complying with such an argument is the observation of Schweitzer \& Simon (1995) of carbon limitation of Lake Constance bacterioplankton from December until onset of the spring phytoplankton bloom. In stratified, high-light environments, however, presently available data are probably insufficient for making general statements as to which of the 4 classes of models is appropriate. In the case of $P$-limited environments, there are data suggesting that both phytoplankton and heterotrophic bacteria may be P-limited (Thingstad et al. 1993, Pomeroy et al. 1995), and we have previously suggested that models of Class 3 may be used to explain DOC accumulation in the photic zone and subsequent transport of DOC to the deep ocean (Thingstad \& Rassoulzadegan 1995, Thingstad et al. 1997).

The suit of model classes investigated here certainly does not cover all theoretical possibilities. One example would be the case of each bacterial species being a specialist for certain substrates. If there is a huge number of such substrates produced by the ecosystem, each specialist would never reach an abundance sufficient for viruses to survive, and bacterial diversity would in a sense be 'bottom-up' controlled instead of the 'top-down' control suggested here. This particular

Table 2. Summary of controlling mechanisms in the 4 classes of models considered

\begin{tabular}{|lllll|}
\hline Class & $\begin{array}{l}\text { Bacterial abundance } \\
\text { controlled by: }\end{array}$ & $\begin{array}{l}\text { Bacterial growth rate } \\
\text { controlled by: }\end{array}$ & $\begin{array}{l}\text { Infectious viruses } \\
\text { affect bacterial: }\end{array}$ & $\begin{array}{c}\text { Potential accumulation } \\
\text { of DOC }\end{array}$ \\
\hline 1 & $\begin{array}{l}\text { Bacterivorous } \\
\text { heterotrophic } \\
\text { flagellates } \\
\text { Bacterivorous } \\
\text { heterotrophic } \\
\text { flagellates } \\
\text { Bacterivorous } \\
\text { heterotrophic } \\
\text { flagellates } \\
\text { Bacterivorous } \\
\text { heterotrophic } \\
\text { flagellates }\end{array}$ & $\begin{array}{l}\text { System production rate of } \\
\text { degradable DOC }\end{array}$ & Degradability of DOC & Diversity \\
4 & $\begin{array}{l}\text { Concentration of mineral nutrient } \\
\text { Concentration of mineral } \\
\text { nutrient and system } \\
\text { production rate of organic } \\
\text { form of mineral nutrient }\end{array}$ & Diversity & Yes \\
\hline
\end{tabular}


concept has been discussed by Hobbie \& Fletcher (1988), who concluded that data available from autoradiography and uptake kinetics give little evidence of such specialisation. Several authors (Lignell et al. 1992, Elser et al. 1995, Schweitzer \& Simon 1995) have found that the addition of several substrates has been necessary to stimulate bacterial growth. This could mean that systems often are nearly balanced, and that addition of 1 nutrient leads to an almost immediate transition into another type of limitation, but it may also mean that more complicated models assuming several factors simultaneously limiting bacterial growth rate may be required.

We have not considered variable yield in these models. Since $Y_{\mathrm{BC}}$ is an explicit parameter, the effect of large or small $Y_{\mathrm{BC}}$ can of course easily be deduced, and as expected, a low bacterial yield on organic carbon will give a high carbon demand and make the C-limited situations (Classes 1 and 2) more probable than the mineral nutrient-limited ones (Classes 3 and 4). More interesting are models linking $Y_{\mathrm{BC}}$ to bacterial growth rate and type of limitation. A low carbon yield under mineral nutrient limitation would decrease the rate of accumulation of DOC in Class 3 and 4 models. In models of Class 3 , bacterial growth rate will generally decrease as the system becomes more oligotrophic; decreasing carbon yield at low growth rates would thus increase the probability for C limitation of bacteria in oligotrophic systems.

Our analysis presents a message both to modelers and experimentalists. The possibility to suggest plausible explanations for alternatives of observable behavior should be a valuable tool in experimental ecology. All 4 classes of models are described with parameters that directly relate to biological and chemical quantities of which most are measurable. In principle, design of experiments aimed at refuting some of the models should thus be practically possible. As an example, a response in bacterial production, or lack of such, to addition of an easily degradable carbon source should be an appropriate test separating Classes 1 and 2 from Classes 3 and 4 .

Complex simulation models of the microbial food web are approaching a state where a remarkable fit is obtained between model output and observed system behaviour (Baretta-Bekker et al. 1995), and one may start to hope that these can become vaiuabie predictive tools. Most such models contain as building blocks the mechanisms discussed here. Our analysis should therefore be able to provide information about the consequences of making different assumptions influencing bacteria inside large simulation models. With its great transparency, this analysis should also be of potential help in the process of understanding the link between properties included in the equations of large simulation models, and the output produced by these models.
Acknowledgements. This work was financed via EU MASTIII contract MAS3-CT95-0016 'Medea' to F.T and a grant from NORFA to R.L.

\section{LITERATURE CITED}

Ammerman JW, Azam F (1991) Bacterial 5'-nucleotidase activity in estuarine and coastal marine waters: characterization of enzyme activity. Limnol Oceanogr 36:1427-1436

Baretta-Bekker J, Baretta JW, Koch Rasmussen E (1995) The microbial food web in the European regional seas ecosystem model. Neth J Sea Res 33:363-379

Bergh Ø, Børsheim KY, Bratbak G, Heldal M (1989) High abundance of viruses found in aquatic environments. Nature 340:467-468

Bratbak G, Thingstad TF (1985) Phytoplankton-bacteria interactions: an apparent paradox? Analysis of a model system with both competition and commensalism. Mar Ecol Prog Ser 25:23-30

Elser J, Stabler LB, Hasset RP (1995) Nutrient limitation of bacterial growth and rates of bacterivory in lakes and oceans: a comparative study. Aquat Microb Ecol 9:105-110

Fuhrman JA, Azam F (1982) Thymidine incorporation as a measure of heterotrophic bacterioplankton production in marine surface waters: evaluation and field results. Mar Biol 66:109-120

Fuhrman JA, Lee SH, Masuchi Y, Davis AA, Wilcox RM (1994) Characterization of marine prokaryotic communities via DNA and RNA. Microb Ecol 28:133-145

Hobbie J, Fletcher MM (1988) The aquatic environment. In: Lynch J, Hobbie JE (eds) Micro-organisms in action. Blackwell Scientific Publications, Oxford, p 148

Hofle M, Brettar I (1995) Taxonomic diversity and metabolic activity of microbial communities in the water column of the central Baltic Sea. Limnol Oceanogr 40:868-874

Kirchman D (1994) The uptake of inorganic nutrients by heterotrophic bacteria. Microb Ecol 28:255-271

Kirchman D, Suzuki Y, Garside C, Ducklow HW (1991) High turnover rates of dissolved organic carbon during a spring phytoplankton bloom. Nature 352:612-614

Lignell R, Kaitala S, Kuosa H (1992) Factors controlling phytoand bacterioplankton in late spring on a salinity gradient in the northern Baltic. Mar Ecol Prog Ser 84:121-131

Maynard Smith J (1974) Models in ecology. Cambridge University Press, Cambridge

Olsen $R$, Chisholm SW, Zettler ER, Altabet MA, Dusenberry JA (1991) Spatial and temporary distributions of prochlorophyte picoplankton in the North Atlantic Ocean. Deep Sea Res 37:1033-1051

Pantoja S, Lee C (1994) Cell-surface oxidation of amino acids in seawater. Limnol Oceanogr 39:1718-1725

Pomeroy L, Sheldon JE, Sheldon WM Jr, Peters F (1995) Limits to growth and respiration of bacterioplankton in the Gulf of Mexico. Mar Ecol Prog Ser 117:259-268

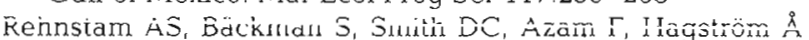
(1993) Blooms of sequence-specific culturable bacteria in the sea. FEMS Microbiol Ecol 102:161-166

Schweitzer B, Simon M (1995) Growth limitation of planktonic bacteria in a large mesotrophic lake. Microb Ecol 30:89-104

Thingstad T (1992) Modelling the microbial food web structure in pelagic ecosystems. Arch Hydrobiol Beih 37:111-119

Thingstad TF, Bratbak G, Heldal M, Dundas I (in press) Trophic interactions controlling diversity in pelagic microbial food webs. Proceedings of the 7 th International Symposium in Microbial Ecology (ISME-7), Santos, Brazil, 27 August-1 September 1995 
Thingstad TF, Hagström $\AA$, Rassoulzadegan F (1997) Export of degradable DOC from oligotrophic surface waters: caused by a malfunctioning microbial loop? Limnol Oceanogr 42:398-404

Thingstad TF, Rassoulzadegan F (1995) Nutrient limitations, microbial food webs, 'biological C-pumps'. suggested interactions in a P-limited Mediterranean. Mar Ecol Prog Ser 117:299-306

Thingstad TF, Skjoldal EF, Bohne RA (1993) Phosphorus cycling and algal-bacterial competition in Sandsfjord, western Norway. Mar Ecol Prog Ser 99:239-259

Responsible Subject Editor: J. Dolan, Villefranche-sur-Mer, France
Wilcox RM, Fuhrman JA (1994) Bacterial viruses in coastal seawater: lytic rather than lysogenic production. Mar Ecol Prog Ser 114:35-45

Williams PJleB (1995) Evidence for the seasonal accumulation of carbon-rich dissolved organic material, its scale in comparison with changes in particulate material and the consequential effect on net $\mathrm{C} / \mathrm{N}$ assimilation ratios. Mar Chem 51:17-29

Zimmermann R, Meyer-Reil LA (1975) A new method for fluorescence staining of bacterial populations on membrane filters. Kieler Meeresforsch 30:24-27

Manuscript received: October 29, 1996

Revised version accepted: April 15, 1997 